\title{
Impaired pattern separation in Tg2576 mice is associated with hyperexcitable dentate gyrus caused by Kv4.1 downregulation
}

\author{
Kyung-Ran Kim ${ }^{1 \dagger}$, Yoonsub Kim ${ }^{1 \dagger}$, Hyeon-Ju Jeong ${ }^{4}$, Jong-Sun Kang ${ }^{4}$, Sang Hun Lee ${ }^{1,5}$, Yujin Kim ${ }^{1,2}$, \\ Suk-Ho Lee ${ }^{1,2,3}$ and Won-Kyung Ho $\mathrm{H}^{1,2,3^{*}}$ (1)
}

\begin{abstract}
Alzheimer's disease (AD) is a progressive neurodegenerative disorder that causes memory loss. Most AD researches have focused on neurodegeneration mechanisms. Considering that neurodegenerative changes are not reversible, understanding early functional changes before neurodegeneration is critical to develop new strategies for early detection and treatment of AD. We found that Tg2576 mice exhibited impaired pattern separation at the early preclinical stage. Based on previous studies suggesting a critical role of dentate gyrus (DG) in pattern separation, we investigated functional changes in DG of Tg2576 mice. We found that granule cells in DG (DG-GCs) in Tg2576 mice showed increased action potential firing in response to long depolarizations and reduced 4-AP sensitive $\mathrm{K}^{+}$-currents compared to DG-GCs in wild-type (WT) mice. Among Kv4 family channels, Kv4.1 mRNA expression in DG was significantly lower in Tg2576 mice. We confirmed that Kv4.1 protein expression was reduced in Tg2576, and this reduction was restored by antioxidant treatment. Hyperexcitable DG and impaired pattern separation in $\operatorname{Tg} 2576$ mice were also recovered by antioxidant treatment. These results highlight the hyperexcitability of DG-GCs as a pathophysiologic mechanism underlying early cognitive deficits in $A D$ and Kv4.1 as a new target for $A D$ pathogenesis in relation to increased oxidative stress.
\end{abstract}

Keywords: Tg2676, Intrinsic excitability, Dentate gyrus, Kv4.1, Alzheimer's disease

\section{Introduction}

Alzheimer's disease (AD) is a progressive neurodegenerative disorder and is the most common cause of dementia. Considerable evidence has indicated that $\mathrm{AD}$ patients exhibit cognitive decline several years before clinical diagnosis [1-3]. In particular, assessment of episodic memory is the most effective method for identifying at-risk individuals $[3,4]$. Synaptic loss associated with a decline in basal synaptic transmission and a deficit in induction of long-term potentiation (LTP) have been

\footnotetext{
*Correspondence: wonkyung@snu.ac.kr

${ }^{\dagger}$ Kyung-Ran Kim and Yoonsub Kim contributed equally to this work

1 Department of Physiology, Seoul National University College of Medicine, 103 Daehak-ro, Jongno-gu, Seoul 03080, Korea

Full list of author information is available at the end of the article
}

identified as potential underlying mechanisms for ADassociated cognitive declined [5-7]. Synaptic loss and deficits were shown to be mediated by amyloid $\beta(A \beta)$ and Tau oligomers, or epigenetic alterations [7]. On the other hand, $\mathrm{AD}$ pathogenesis also exhibits a profound increase in hyperactive neurons $[8,9]$. Aberrant network activity associated with increased seizure are also considered as important factors causing cognitive decline [10]. It is not yet fully understood how $A \beta$ and Tau are involved in both synaptic depression and neuronal hyperexcitability or how they are related to aberrant network activity and cognitive decline.

Synaptic dysfunction is widely thought to be one of the earliest key pathogenic events in AD before frank neurodegeneration, and the hippocampal network is original author(s) and the source, provide a link to the Creative Commons licence, and indicate if changes were made. The images or other third party material in this article are included in the article's Creative Commons licence, unless indicated otherwise in a credit line to the material. If material is not included in the article's Creative Commons licence and your intended use is not permitted by statutory regulation or exceeds the permitted use, you will need to obtain permission directly from the copyright holder. To view a copy of this licence, visit http://creativecommons.org/licenses/by/4.0/. The Creative Commons Public Domain Dedication waiver (http://creativeco mmons.org/publicdomain/zero/1.0/) applies to the data made available in this article, unless otherwise stated in a credit line to the data. 
particularly vulnerable in AD [11-14]. The hippocampus is divided into three main fields, the dentate gyrus (DG) and areas CA3 and CA1, and each field displays distinctive anatomical, molecular, and biophysical properties $[15,16]$. Although all three hippocampal pathways have been associated with learning and memory, MF-CA3 projection specifically has been implicated in cognitive function, including novelty detection, pattern completion and pattern separation $[17,18]$. Indeed, structural and functional MRI analysis of AD patients revealed disruption of the mossy fiber (MF)-CA3 pathway in patients with mild AD or mild cognitive impairment $[19,20]$. Synaptic activity in the DG/CA3 network was proposed as an early target of amyloid pathology that leads to impaired pattern separation and episodic memory loss [21]. Consistently, impaired synaptic plasticity in MF-CA3 synapses at an early stage in AD model mice was reported $[22,23]$. However, it remains to be elucidated how alteration of intrinsic excitability contributes to impaired DG/ CA3 network underlying AD-associated cognitive deficit.

Sparseness of DG activity is a prerequisite for orthogonal representation of information which is critical for pattern separation function [24,25]. This hypothesis was supported by an experiment showing that hyperexcitability of GCs in DG induced by selective degeneration of hilar mossy cells led to impaired pattern separation [26]. We have recently reported that low excitability of mature GCs is attributable to a high level of Kv4.1 expression, and knock-down of Kv4.1 in DG causes hyperexcitability and impaired pattern separation [27]. In the present study, we investigated the possible role of Kv4.1 in impaired pattern separation in the early preclinical stage of $\mathrm{AD}$, and found that GCs in Tg2576 mice showed hyperexcitability and reduced Kv4.1. Furthermore, hyperexcitability and reduced Kv4.1 in Tg2576 GCs and impaired pattern separation in $\mathrm{Tg} 2576$ mice were reversed by antioxidant treatment. These results highlight the hyperexcitability of GCs in DG as a pathophysiologic mechanism underlying early cognitive deficits in $\mathrm{AD}$, and $\mathrm{Kv} 4.1$ as a new target for $\mathrm{AD}$ pathogenesis in relation to increased oxidative stress.

\section{Results}

\section{Impaired pattern separation in Tg2576 mice}

To investigate cognitive impairment in an early stage of AD before expressing amyloid plaque deposition and severe memory loss, we used $3 \sim 4$ months-old Tg2576 mice and performed contextual fear discrimination tests [28]. After giving a single shock once a day for first 3 days in context A (contextual fear acquisition), generalization protocol was performed on day 4 and 5 without giving a shock in a similar pair of contexts (A and B) that had identical metal grid floors, while context B had a unique odor (1\% acetic acid) with dimmer lighting
(50\% of A) in the sloped floor (15 angle) (Fig. 1A). We observed that both WT and Tg2576 groups showed comparable freezing responses during 5 min test in context A (Fig. 1Ba). Moreover, freezing levels were not different between context $\mathrm{A}$ and $\mathrm{B}$ in both genotypes (Fig. 1Bb, WT, Tg2576, two-way ANOVA, genotype: $F_{(1,30)}=0.24$, $\mathrm{p}=0.62$, context: $\mathrm{F}_{(1,30)}=0.15, \mathrm{p}=0.70$, genotype $\times$ context: $\left.\mathrm{F}_{(1,30)}=0.39, \mathrm{p}=0.54\right)$. The mice were subsequently trained to disambiguate these contexts by visiting both contexts daily for 8 days with a 2 -h-interval between the contexts (from day 6 to day 13), always receiving a foot shock $180 \mathrm{~s}$ after being placed in context $\mathrm{A}$ but not in context B (Fig. 1A). A daily discrimination ratio was calculated by freezing during the $180 \mathrm{~s}$ in context $\mathrm{A}$ over total freezing during the two visits (Fig. 1Ca). On day 6, both groups showed a low level of freezing (Additional file 1: Fig. S1) and could not distinguish the differences between two contexts (Fig. 1Ca, genotype: $F_{(1,24)}=3.67$, $\mathrm{p}=0.06$, context: $\mathrm{F}_{(1,24)}=0.73, \mathrm{p}=0.40$, genotype $\times$ context: $\left.F_{(1,24)}=0.31, p=0.58\right)$; thus, the discrimination ratio was approximately 0.5 . Over subsequent training days, WT mice began to freeze profoundly in context A, but not in context B (Additional file 1: Fig. S1), resulting in an increase in discrimination ratio (Fig. 1Ca). However, $\operatorname{Tg} 2576$ mice showed increased freezing in both in context A and B (Additional file 1: Fig. S1 and Fig. 1Cb, t-test, Context $\mathrm{B}, \mathrm{p}<0.0001$, Two-way ANOVA, genotype: $\mathrm{F}_{(1,25)}=0.25, \mathrm{p}=0.62$, context: $\mathrm{F}_{(1,25)}=19.19, \mathrm{p}<0.0001$, genotype $\times$ context: $\left.\mathrm{F}_{(1,25)}=34.63, \mathrm{p}<0.000004\right)$, exhibiting significant deficits in the acquisition of discrimination ability (Fig. 1Ca). To rule out the possibility that general memory acquisition or storage is impaired in Tg2676 mice, the context specificity of the conditioning was examined using context $\mathrm{A}$ and context $\mathrm{C}$ that is distinct from context $\mathrm{A}$. In this configuration, context $\mathrm{C}$ evoked a significantly lower level of freezing than context $\mathrm{A}$ in both genotypes (Fig. 1D, genotype: $F_{(1,14)}=0.16, p=0.70$, context: $F_{(1,14)}=43.78, \quad p<0.000012$, genotype $\times$ context: $\left.\mathrm{F}_{(1,11)}=0.06, \mathrm{p}=0.80\right)$. These results indicate that $3 \sim 4$-month-old Tg2576 mice exhibit specific impairment in pattern separation between similar contexts without deficits in memory acquisition or learning. We did not perform other behavioral tests, but it was reported that motor functions and anxiety levels were normal in aged Tg2576 mice [29].

\section{Hyperexcitability and reduced $\mathrm{K}^{+}$currents in Tg2576 GCs in DG}

To investigate the possibility that the abnormal excitability of granule cells (GCs) in dentate gyrus (DG) is involved in the impairments of pattern separation in $\operatorname{Tg} 2576$ mice, we examined intrinsic properties of GCs. To avoid the neural progenitor cells and newborn 


\section{A Pattern separation}

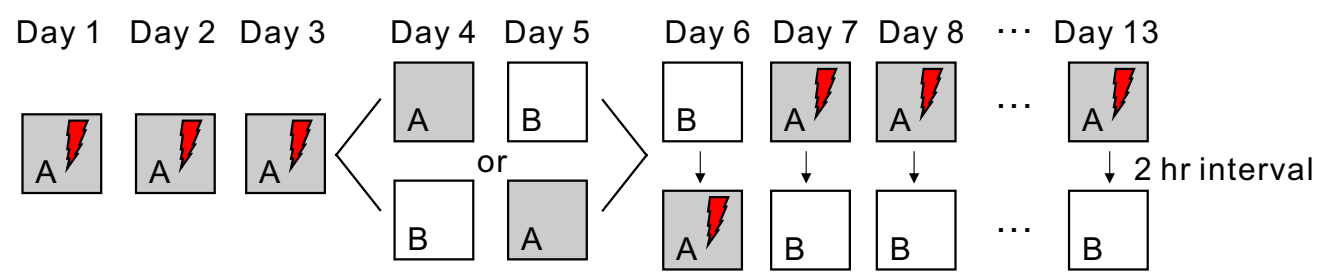

Ba

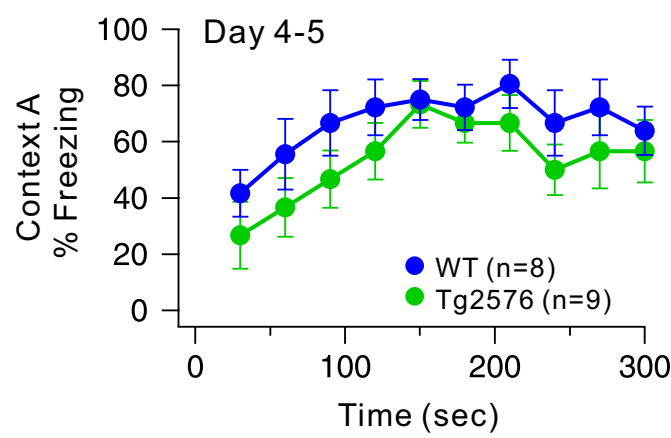

$\mathrm{Ca}$

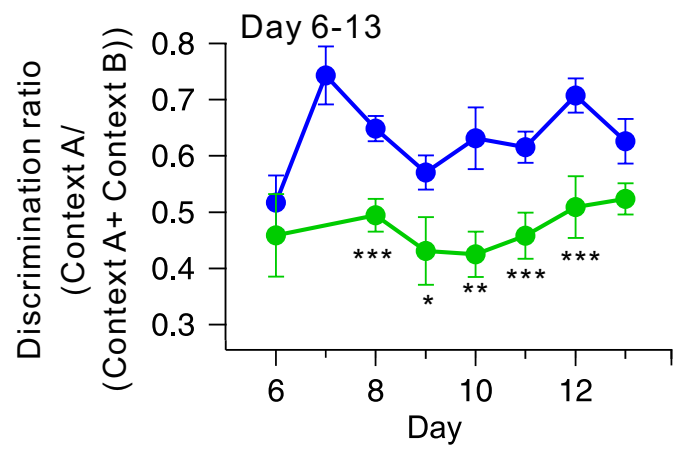

Da

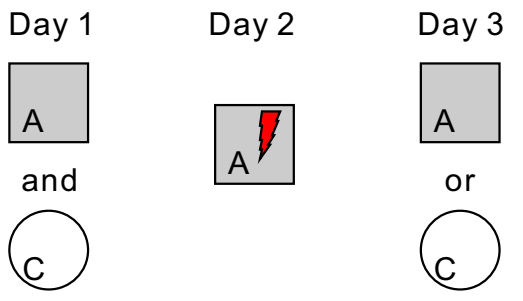

Bb

Context $\mathrm{A}$

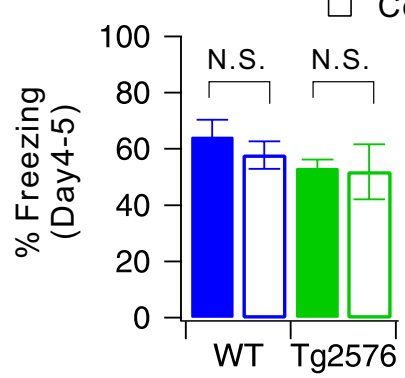

$\mathrm{Cb}$

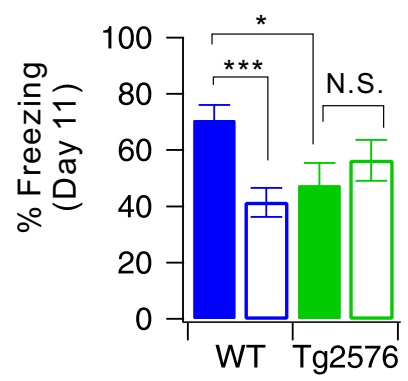

Db
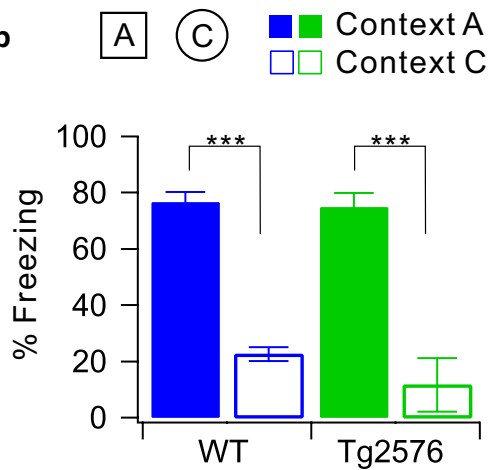

Fig. 1 Impaired pattern separation in Tg2576 mice. A Experimental procedure for pattern separation in 10-week-old WT and Tg2576 mice. Ba On day 4 to 5 , the kinetics of freezing across the 5 min test in context $\mathbf{A}$. Bb Percentage of freezing in context A (filled bar) and context B (open bar) during day 4-5. WT (blue, $n=8$ ) and Tg2576 (green, $n=9$ ) mice displayed equal amounts of freezing in both contexts A and B. Ca On day 6 to 13 , time course of the discrimination ratio in WT (blue, $n=8$ ) and Tg2576 (green, $n=7$ ) mice. Statistical significance for each day was tested using ANOVA $\left({ }^{*} P<0.05 ;{ }^{*} P<0.01\right.$; $\left.{ }^{* *} P<0.001\right)$. Cb Percentage of freezing in context A (filled bar) and context B (open bar) for WT (blue, $n=8$ ) and $\operatorname{Tg} 2576$ (green, $n=7$ ) mice on day 11. Freezing levels were compared between the two contexts for each group (N.S., no statistical significance; $\left.{ }^{*} P<0.05\right)$. Da Experimental procedure for one-trial contextual fear conditioning between WT $(n=8)$ and $\operatorname{Tg} 2576(n=7)$ mice. Db The percentage of freezing in context A (filled bar) and context C (open bar, distinct object) for WT ( $n=8)$ and $\operatorname{Tg} 2576(n=7)$ mice 
immature neurons, we identified mature DG granule neurons in the hippocampus according to their morphological and electrophysiological criteria: low resting membrane potential (RMP) and input resistance $\left(\mathrm{R}_{\mathrm{in}} ;<200 \mathrm{M} \Omega\right)$ located in the outer molecular layer [27, 30]. We found that firing frequency evoked by depolarizing pulses of $1 \mathrm{~s}$ duration was significantly higher in the Tg2576 GCs (green, Fig. 2A) compared to the WT GCs (blue, Fig. 2A). The relationship of action potential (AP) frequency (F) versus injected currents (I) showed an upward shift in DG neurons of Tg2576 mice relative controls, indicating increased neuronal excitability (Fig. 2Ab). In agreement with these findings, the AP onset time during AP trains was also significantly shorter in Tg2576 GCs (Fig. 2B; $34.7 \pm 1.3 \mathrm{~ms}, n=13$, for WT and $24.6 \pm 1.6 \mathrm{~ms}, n=12$, for $\mathrm{Tg} 2576$ at $300 \mathrm{pA}$ current injection, $p=0.000045)$. However, we did not find significant differences between $\operatorname{Tg} 2576$ and WT mice in passive electrical properties, such as RMP, $R_{\text {in }}$ and threshold current for the AP generation (Rheobase) (Fig. 2C; RMP:
Aa

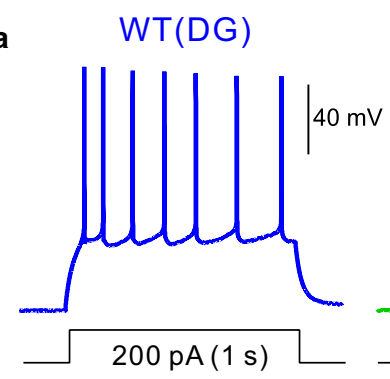

B

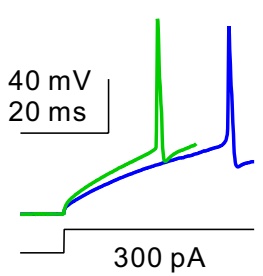

$\mathrm{Da}$

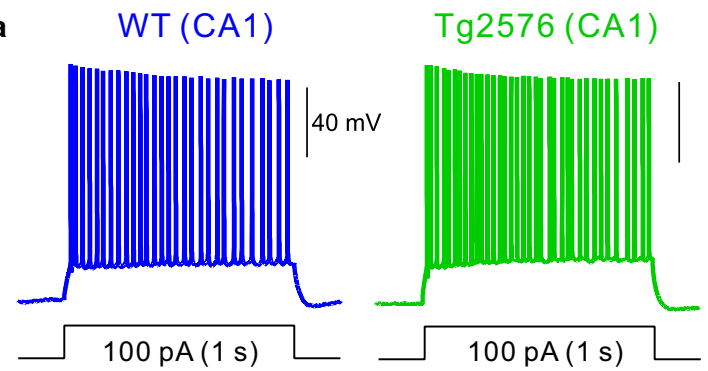

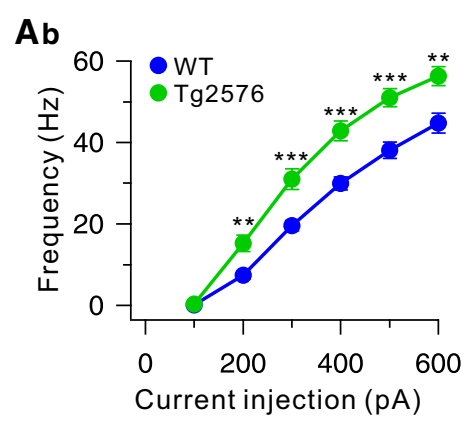

C $\quad \operatorname{RMP}(\mathrm{mV})$

$R_{\text {in }}(M \Omega)$

Rheobase (pA)
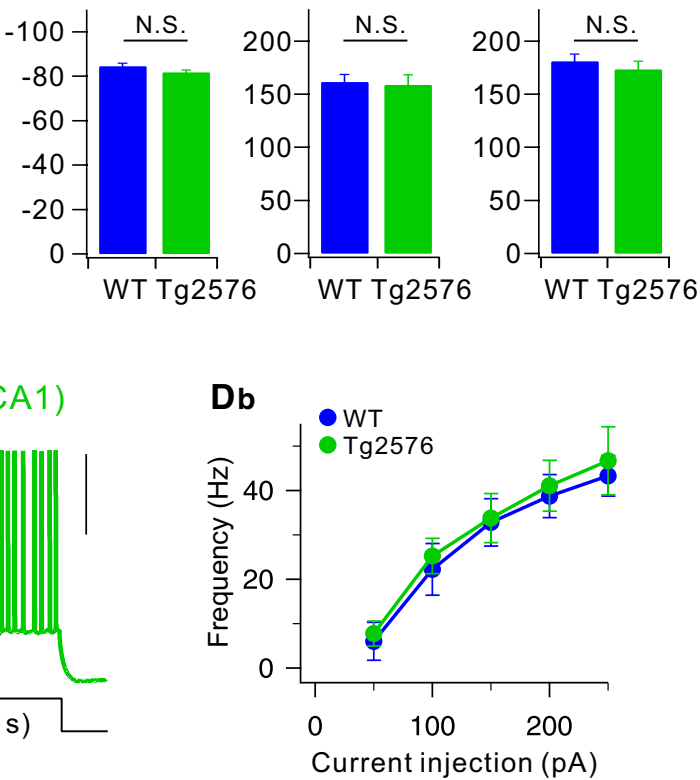

Fig. 2 Electrophysiological analysis for the excitability of WT and Tg2576 mice. Aa Representative traces in the current-clamp recording from the WT (blue) and Tg2576 (green) dentate GCs in response to prolonged (1 s) depolarizing current injection (200 pA). Ab Number of spike evoked during $1 \mathrm{~s}$ current injections with varying amplitudes (from 100 to 600 pA, 100 pA increment). At all amplitudes, the number of spikes is significantly higher in Tg2576 GCs (green closed circle, $n=14$ ) compared to WT GCs (blue closed circle, $n=15$ ). Mean \pm S.E.M. ${ }^{* *} P<0.01 ;{ }^{* * *} P<0.001$ B Expanded view of overlaid 1st APs evoked by 300 pA current injection to show the shortening of AP onset in Tg2576 GCs compared to WT GCs. Mean \pm S.E.M. ${ }^{* * *} P<0.001$ C The mean values of the resting membrane potential (WT: $-84.5 \pm 1.3 \mathrm{mV}, \mathrm{Tg} 2576:-81.8 \pm 1.0 \mathrm{mV}$ ), input resistance

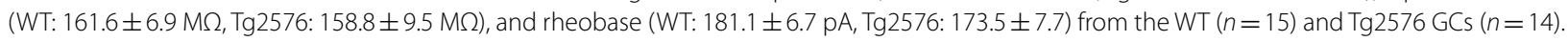
Mean \pm S.E.M. N.S., not significantly different. Da Representative traces of current-clamp recordings from CA1 of WT (blue) and Tg2576 mice (green). A train of APs were evoked by $1 \mathrm{~s}$ depolarizing current pulse injection (100 pA). Db The F-I curve for CA1 from WT $(n=4)$ and Tg2576 $(n=4)$ mice 
$\mathrm{p}=0.11641, \quad \mathrm{R}_{\mathrm{in}}: \mathrm{p}=0.8121$, Rheobase: $\left.\mathrm{p}=0.46504\right)$. However, unlike DG GCs, the excitability of CA1 pyramidal neurons was not different between Tg2576 and WT mice (Fig. 2D), suggesting the GC-specific hyperexcitability in $\operatorname{Tg} 2576$ mice. These results suggest that the enhanced excitability of GCs in Tg2576 mice is unlikely to be attributable to the alteration of $\mathrm{Na}^{+}$channels or ion channels in determining the subthreshold membrane excitability. We therefore hypothesized that downregulation of Kv4.1 channels that play key roles in low excitability of mature GCs [27] may cause the hyperexcitability of Tg2576 GCs.

To examine this hypothesis, we first recorded $\mathrm{K}^{+}$currents in the voltage clamp mode by applying depolarizing voltage steps (ranging from $-60 \mathrm{mV}$ to $+30 \mathrm{mV}$ with $10 \mathrm{mV}$ increment and $1 \mathrm{~s}$ duration) at a holding potential of $-70 \mathrm{mV}$. TTX, $\mathrm{Cd}^{2+} / \mathrm{Ni}^{2+}$, bicuculline, and CNQX were added to the external solution to block $\mathrm{Na}^{+}$channels, $\mathrm{Ca}^{2+}$ channels, $\mathrm{GABA}_{\mathrm{A}}$ receptors, and AMPA/ kainate receptors, respectively. We found that total outward $\mathrm{K}^{+}$currents in Tg2576 GCs are similar to that in WT GCs (Fig. 3A), while $\mathrm{K}^{+}$currents sensitive to $5 \mathrm{mM}$ 4-AP $\left(\mathrm{I}_{4-\mathrm{AP}}\right)$ are substantially less in $\mathrm{Tg} 2576 \mathrm{GCs}$ relative to WT GCs (Fig. 3B). The difference was found both in the peak current $\left(\mathrm{I}_{\text {peak }}\right)($ at $+30 \mathrm{mV}$; WT: $2.234 \pm 0.203$ $\mathrm{nA}, n=9, \operatorname{Tg} 2576 ; 1.624 \pm 0.197 \mathrm{nA}, n=7, \mathrm{p}=0.0477)$ and in the steady state current $\left(\mathrm{I}_{\mathrm{ss}}\right)$ (at $+30 \mathrm{mV}$; WT: $0.505 \pm 0.042 \mathrm{nA}, n=9$, Tg2576: $0.161 \pm 0.037 \mathrm{nA}, n=7$, $\mathrm{p}=0.000197$ ). Notably, reduction of $\mathrm{I}_{\mathrm{ss}}$ was greater than $\mathrm{I}_{\text {peak }}$ in $\mathrm{Tg} 2576$, suggesting that reduced $\mathrm{I}_{4-\mathrm{AP}}$ in $\mathrm{Tg} 2576$ GCs is attributable to downregulation of $\mathrm{K}^{+}$channels that inactivate slowly. We further analyzed the difference in $\mathrm{I}_{4-\mathrm{AP}}$ between WT and Tg2576 GCs (Fig. 3C). To further analyze inactivation of $\mathrm{I}_{4-\mathrm{AP}}$, we fitted inactivation phases of $\mathrm{I}_{4-\mathrm{AP}}$ with a two-exponential decay function, $I(t)=A_{\text {fast }} \exp \left(-t / \tau_{\text {fast }}\right)+A_{\text {slow }} \exp \left(-t / \tau_{\text {slow }}\right)$. The results showed that the amplitude of the slow component $\left(\mathrm{A}_{\text {slow }}\right)$ was selectively reduced in the Tg2576 GCs compared to WT GCs, whereas the other parameters $\left(\mathrm{A}_{\text {fast }}, \tau_{\text {fast, }}\right.$, and $\tau_{\text {slow }}$ ) were not altered (Fig. $3 C$ ). Considering that the slowly inactivating component of $\mathrm{I}_{4-\mathrm{AP}}$ in GCs was mainly attributable to Kv4.1 current [27], these results suggest that reduced $\mathrm{I}_{4-\mathrm{AP}}$ in Tg2576 GCs is attributable to the decrease in Kv4.1 current.

\section{Kv4.1 downregulation is responsible for hyperexcitability of Tg2576 GCs}

To investigate the molecular identity of the decreased $\mathrm{I}_{4-\mathrm{AP}}$ in Tg2576 GCs, we examined whether mRNA expression levels of $\mathrm{Kv} 4$ family channels are altered using quantitative Real-Time PCR (qRT-PCR) techniques. We found that the Kv4.1 mRNA expression level in DG was significantly lower in $\mathrm{Tg} 2576$, while $\mathrm{Kv} 4.2$ and $\mathrm{Kv} 4.3$
mRNA expressions levels were not altered (Fig. 4A; Kv4.1: $\mathrm{p}=0.000058, \mathrm{Kv} 4.2: \mathrm{p}=1, \mathrm{Kv} 4.3: \mathrm{p}=0.62857$, Mann-Whitney test). These results suggest that Kv4.1 expression was selectively downregulated in $\operatorname{Tg} 2576$ without compensation by the other Kv4 channel subunits. In agreement with these findings, $\mathrm{Kv} 4.1$ protein level in DG was also significantly lower in Tg2576 compared to WT (Fig. 4B). To examine the functionality of reduced Kv4.1 expression in $\mathrm{Tg} 2576$, we examined the effects of Kv4.1 antibody perfusion via a whole-cell patch pipette on firing frequency. In WT GCs, action potential firing evoked by depolarizing pulses of $1 \mathrm{~s}$ duration was increased significantly by Kv4.1 antibody (from $7.6 \pm 0.9$ to $14.2 \pm 3.2, n=5, p=0.00718$, Fig. $4 \mathrm{C}$ ), which is consistent with our previous results in GCs of C57BL/6 control mice [27]. These results confirmed that $\mathrm{Kv} 4.1$ contributes to lowering firing frequency in GCs in WT as in C57BL/6 mice. In contrast, firing frequency was not significantly affected by Kv4.1 antibody in Tg2576 GCs $(15.2 \pm 1.9$ vs $17.3 \pm 2.9, \mathrm{p}=0.64891$, Fig. $4 \mathrm{C}$ ). It was also noted that firing frequency of WT GCs with Kv4.1 antibody was comparable with that of Tg2576 GCs ( $p=0.79502$, Fig. 4C). These results support the idea that Kv4.1 is responsible for limiting AP firing in WT GCs, and that reduced Kv4.1 in Tg2576 GCs is a key mechanism for enhanced excitability in Tg2576 GCs.

\section{Hyperexcitability of Tg2576 GCs and impaired pattern separation in $\mathrm{Tg} 2576$ mice are restored by antioxidant treatment}

We previously reported that mitochondrial reactive oxygen species (ROS) production is increased in Tg2576 DG at the age of 1- to 2-months, causing depolarization of mitochondrial membrane potential and impairment of $\mathrm{Ca}^{2+}$ uptake int mitochondria. Furthermore, this impairment is restored by treatment of antioxidant, Trolox [31]. We have recently reported that calbindin, a major $\mathrm{Ca}^{2+}$ buffer in dentate GCs, is crucial for Kv4.1 activity, and that calbindin knockout mice also show hyperexcitable DG, reduced $\mathrm{K}^{+}$currents, and impaired pattern separation [32]. Interestingly, $\mathrm{Ca}^{2+}$ buffer capacity of $\mathrm{Tg} 2576 \mathrm{GCs}$ is as low as that in calbindin knockout mice, and it is restored by Trolox [32], suggesting that calbindin is a target of oxidative stress. We therefore addressed the question whether ROS overproduction underlies hyperexcitability in $\mathrm{Tg} 2576$ GCs due to Kv4.1 downregulation. To this end, we first examined the effects of Trolox on the hyperexcitability phenotype in the Tg2576 GCs. Preincubation of $\mathrm{Tg} 2576 \mathrm{GCs}$ in the aCSF containing Trolox $(500 \mu \mathrm{M})$ for $1 \mathrm{~h}$ did not affect the relationship of AP frequency and injected currents (orange, Fig. 5A), while injection of Trolox $(20 \mathrm{mg} / \mathrm{Kg})$ into $\mathrm{Tg} 2576$ mice 


\section{Aa Total $\mathrm{K}^{+}$current}

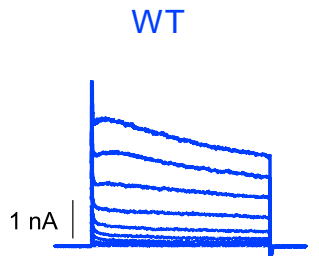

\section{$\operatorname{Tg} 2576$}

$-70 \mathrm{mV} \leftarrow \frac{-60 \text { to }+30 \mathrm{mV}}{1 \mathrm{~s}}-70 \mathrm{mV}-\frac{-60 \text { to }+30 \mathrm{mV}}{1 \mathrm{~s}}$

Ba $5 \mathrm{mM} 4$-AP sensitive current
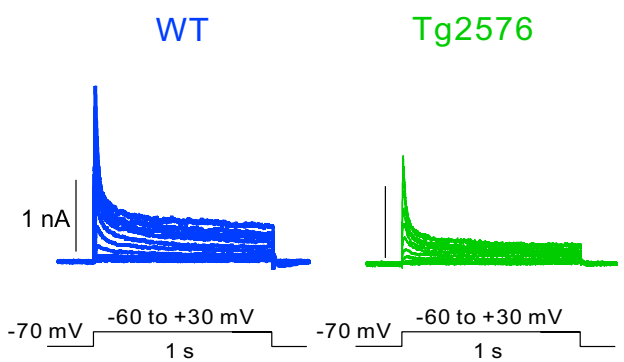

Ab

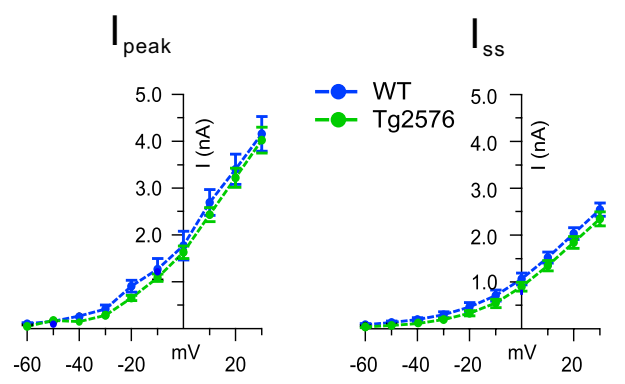

$\mathrm{Bb}$

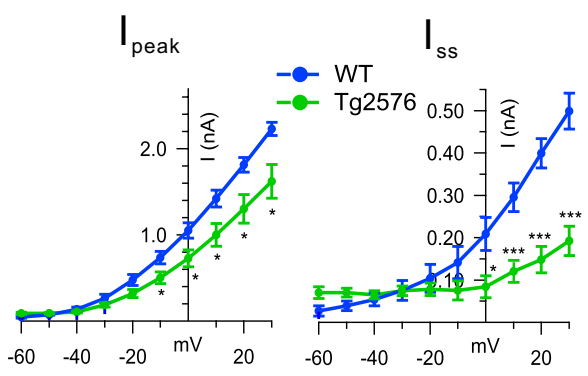

$\mathrm{Ca}$
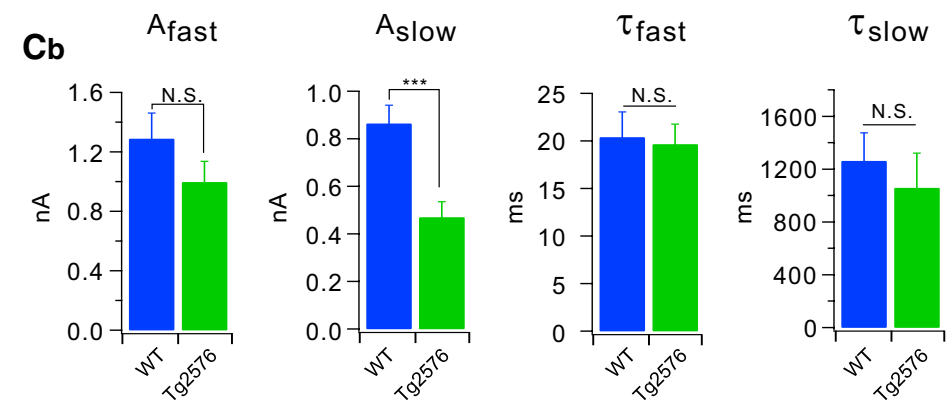

Fig. 3 Voltage-dependent $\mathrm{K}^{+}$currents in the WT and Tg2576. Aa Superimposed current traces evoked by various steps of depolarization (- $60 \mathrm{mV}$ to $+30 \mathrm{mV}$ in $10 \mathrm{mV}$ step) for $1 \mathrm{~s}$ from the holding potential of $-70 \mathrm{mV}$ in the WT (blue) and Tg2576 (green) dentate GCs. Ab Amplitudes of peak currents $\left(I_{\text {peak }}\right)$ and steady state currents $\left(I_{s s}\right)$ measured at the end of depolarization are plotted as a function of the given potential (V). WT (closed blue circle, $n=9$ ) and Tg2576 (closed green circle, $n=7$ ). Ba The difference in currents before and after applying 5 mM 4-AP (l 4 -AP $)$ in the WT (blue) and Tg2576 (green) dentate GCs. Bb $\mathrm{I}_{\text {peak }}$ and $\mathrm{I}_{\text {sS }}$ for $\mathrm{I}_{\text {4-Ap }}$ are plotted as a function of the given potential (V). WT (closed blue circle, $n=9$ ) and Tg2576 (closed green circle, $n=7$ ). $\mathbf{C a ~}_{4-\mathrm{AP}}$ traces obtained at $+30 \mathrm{mV}$ are averaged (WT, blue, $n=9 ;$ Tg2576, green, $n=7$ ) and superimposed. Cb 4-AP $_{\text {. }}$ recorded at $+30 \mathrm{mV}$ were fitted to double-exponential functions. Amplitude and time constant for the fast component $\left(\mathrm{A}_{\text {fast }} \mathrm{T}_{\text {fast }}\right)$ and the slow component $\left(\mathrm{A}_{\text {slow, }} \tau_{\text {slow }}\right)$. Mean \pm S.E.M., ${ }^{* *}, P<0.01,{ }^{* * *}, P<0.001$. N.S. not significantly different, $P>0.05$

intraperitoneally (i.p.) once a day for 1 week induced a downward shift in the relationship of AP frequency and injected currents (purple, Fig. 5A). AP frequency in Tg2576 GCs following Trolox treatment for 1 week is similar to that in WT GCs (dashed blue line, Fig. 5Ab). Consistently, Western blot analysis for Kv4.1 proteins showed a significant increase in Tg2576 mice after 1 week treatment of treated with Trolox (Fig. 5B). These results suggest that restoration of excitability and Kv4.1 expression by Trolox treatment is not a rapid process. We finally examined whether Trolox treatment restored impaired pattern separation in $\mathrm{Tg} 2576$ mice. Contextual fear discrimination tests described in Fig. 1 were performed in Tg2576 mice treated with Trolox for 1 week. Freezing levels during 5 min test at day 4-5 showed comparable freezing levels with those observed in Tg2576 mice (Fig. 5C), while deficits in contextual 


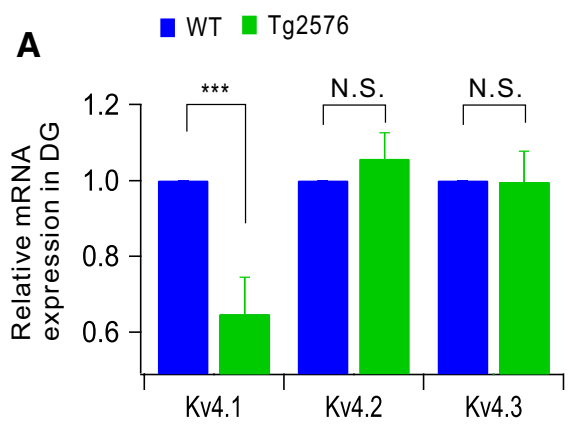

Ca
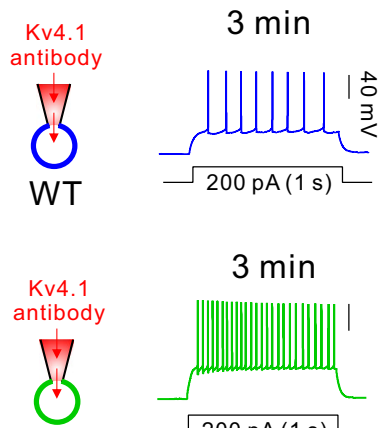

Tg2576
$3 \min$

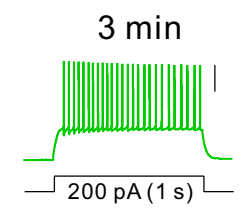

B

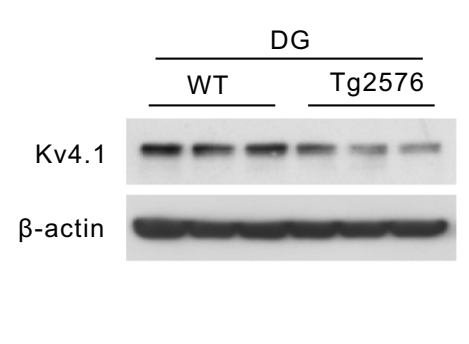

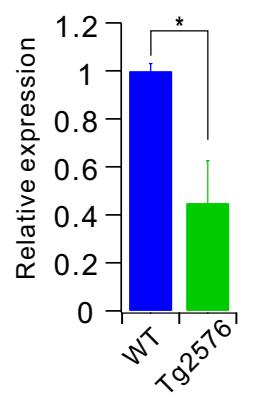

Cb

Fig. 4 Downregulation of Kv4.1 expression in Tg2576 causes hyperexcitability of Tg2576 GCs. A mRNA expression levels for Kv4 family channels in the WT (blue) and Tg2576 (green) DG detected by quantitative RT-PCR. B Western blot analysis for Kv4.1 in DG of 8-week-old mice. For a loading control, $\beta$-actin was used. Right, Kv4.1 expression in Tg2576 was significantly smaller than WT mice. ${ }^{*}, P<0.05$. Ca Example traces of APs evoked by 200 pA current injection immediate ( 3 min, blue for WT and green for Tg2576) and $15 \mathrm{~min}$ (red) after brake-in of patch pipettes containing Kv4.1 antibody. Cb Firing frequency at 200 pA is compared in each conditions

fear discrimination observed in Tg2576 mice (green, Fig. 5D) was restored by Trolox treatment (purple, Fig. 5D). These results support the idea that impaired pattern separation in the early preclinical stage of $A D$ is attributable to the hyperexcitability of GCs mediated by ROS-induced downregulation of Kv4.1.

\section{Discussion}

$\mathrm{AD}$ is characterized as a neurodegenerative disease, although functional deficits occurred prior to neurodegeneration. We reported in our previous study that impaired post-tetanic potentiation was observed at the preclinical stage of $\mathrm{AD}$ [22]. It was demonstrated that mitochondrial dysfunctions such as increased ROS production, partial depolarization of mitochondrial potential, and impaired $\mathrm{Ca}^{2+}$ uptake occurred in dentate GCs of $1 \sim 2$-month-old $\mathrm{Tg} 2576$ mice, leading to the deficits in mitochondria-dependent short-term plasticity at the mossy fiber-CA3 synapses. The observation that antioxidant treatment can restore the reduced short-term plasticity and impaired mitochondrial $\mathrm{Ca}^{2+}$ uptake in
$\operatorname{Tg} 2576$ mice suggests that the increased ROS production in mitochondria initiates the other dysfunctions. In the present study, we revealed that hyperexcitability of GCs caused by Kv4.1 downregulation occurs in the early stage of AD. Furthermore, we showed that impaired pattern separation, possibly an early symptom of cognitive deficit, is linked to hyperexcitability of GCs and that both can be restored by antioxidant treatment. Our study suggests that ion channel remodeling induced by oxidative stress may underlie cognitive deficit in early $\mathrm{AD}$ pathogenesis.

Elevated excitability in the hippocampus has emerged as a key contributor to cognitive impairment in $A D$, though some studies reported reduced intrinsic excitability associated with $\mathrm{AD}[33,34]$. Hyperexcitability including increased firing rate and an elevated number of activated neurons associated with $\mathrm{AD}$ was reported in CA1 [35-37] and CA3 pyramidal neurons [38, 39]. Tight coupling between excitability and cognitive phenotype was also recognized in aging [40]. Reducing hyperexcitability with the antiepileptic drug levetiracetam restores cognitive deficits in $\mathrm{AD}$ as well as in mild cognitive impairments [41-43], indicating the importance 


\begin{abstract}
(See figure on next page.)
Fig. 5 Effect of pre-treatment with Trolox in the Tg2576 mice. Aa Representative trace in the current-clamp recording of pre-treatment with Trolox for one hour (orange) and 1 week (purple) in Tg2576 in response to depolarizing current injection (200 pA with $1 \mathrm{~s}$ duration). Ab F-I curve (from 100 to 600 pA, 100 pA increment) obtained from GCs of Tg2576 mice treated with Trolox for 1 week (Tg + Trolox, purple, $n=8)$ was compared with the F-I curve obtained from Tg2576 GCs (green dashed line, $n=14$ ) shown in Fig. $2 \mathrm{Ab} .{ }^{*}, P<0.05,{ }^{* * *}, P<0.001$. B Western blot analysis for Kv4.1 in DG of 8-week-old Tg2576 mice and those treated with Trolox $(20 \mathrm{mg} / \mathrm{kg}$ ) for 1 week. For a loading control, $\beta$-actin was used. Right, Kv4.1 expression in Tg2576 was significantly increased after Trolox treatment. ${ }^{*}, P<0.01$. Ca On day 4-5, the kinetics of freezing across the 5 min test in context A obtained from Tg2576 mice treated with Trolox for 1 week ( $\mathrm{Tg}+\operatorname{Trolox}$, purple, $n=10$ ) was compared with the that obtained from control $\mathrm{Tg} 2576$ GCs (green, $n=7$ ) shown in Fig. 1Ba. Cb Percentage of freezing in context A (filled bar) and context B (open bar) during day 4 to 5 . Tg2567 (green, $n=7$ ) and $\operatorname{Tg}+$ Trolox (purple, $n=10$ ) mice displayed equal amounts of freezing in both contexts A and B. Da On day 6 to 12 , time course of the discrimination ratio in $\mathrm{Tg}+$ Trolox mice (purple, $n=10$ ) was compared with that obtained from control Tg2576 mice shown in Fig. 1Ca (green, $n=7$ ) mice. Statistical significance for each day was tested using unpaired $t$-test $\left({ }^{*} P<0.05 ;{ }^{*} P<0.01 ;{ }^{* *} P<0.001\right)$. Db Percentage of freezing in context A (filled bar) and context B (open bar) for Tg2576 (green, $n=7$ ) and Tg + Trolox (purple, $n=10$ ) mice on day 11 . Freezing levels were compared between the two contexts for each group. Tg2567 (green, $n=7$ ) mice displayed equal amounts of freezing in both contexts $A$ and $B$, while and $\mathrm{Tg}+$ Trolox (purple, $n=10$ ) mice displayed more freezing in context A compared to context $\mathrm{B}$
\end{abstract}

of hyperexcitability in $\mathrm{AD}$ pathogenesis. However, ion channel mechanisms underlying hyperexcitability were not identified in most studies. Kv4.2 was suggested to be involved in altered excitability in pathologic condition, yet the role is not conclusive. Kv4.2 current was reduced by intracellular accumulation of A $\beta 42$ [37] or Tau [44], while an aging-related increase in A-type potassium currents was attributed to increased firing frequency by facilitating repolarization [39]. In the present study, we not only demonstrated hyperexcitability of GCs in AD model mice, but also identified Kv4.1 downregulation in GCs as underlying mechanism of hyperexcitability. Causal relationship between decreased Kv4.1 expression, hyperexcitability of GCs, and impaired pattern separation in $\operatorname{Tg} 2576$ mice is strongly supported by our previous study [27].

Among many complex factors underlying AD pathogenesis, network abnormality caused by neuronal hyperactivity has recently emerged as a potential mechanism of cognitive dysfunction [10, 45-47] and epileptic seizure $[46,48-50]$. A causal link between $A \beta$ accumulation and network abnormalities and epileptogenesis was proposed $[46,50]$. Functional magnetic resonance imaging (fMRI) of humans with early symptomatic $\mathrm{AD}$ has demonstrated excessive neuronal activities in the hippocampus and neocortex, where $A \beta$ accumulates in abundance [9]. Since neuronal hyperactivity increases extracellular $A \beta$ levels [51], it may initiate a vicious cycle that facilitates progressive pathology and memory impairment [52]. The molecular basis of this hyperexcitability has been examined, and $A \beta$-induced hyperexcitability of layer $2 / 3(\mathrm{~L} 2 / 3)$ pyramidal neurons [45], the dysfunction of parvalbuminpositive interneurons in L2/3 parietal cortex [53], and impaired glutamate reuptake by neurons and astrocytes [50] have been proposed so far. Considering that DG functions as a "gate" controlling information flow from the entorhinal cortex into the rest of the hippocampus, and hyperexcitability of dentate GCs has long been known as one of epileptogenic mechanisms underlying temporal lobe epilepsy $[54,55]$, hyperexcitability of GCs caused by downregulation of Kv4.1 may contribute to network abnormalities associated with increased seizure as well as cognitive impairment associated in AD. Importance of $\mathrm{DG}$ in $\mathrm{AD}$ pathogenesis has been recently highlighted in studies showing restoration of memory in AD mice by optogenetic activation of DG engram cells [56, 57]. DG manipulation may be a potential target for treating cognitive deficit and memory loss in AD.

$\mathrm{Kv} 4.1$ belongs to the Kv4 gene subfamily together with Kv4.2 and Kv4.3 [58-60]. Based on electrophysiological and pharmacological properties, $\mathrm{Kv} 4$ channels are known to mediate A-type $\mathrm{K}^{+}$currents $\left(\mathrm{I}_{\mathrm{A}}\right)$, which are characterized by their rapid inactivation kinetics and their sensitivity to 4-aminopyridine (4-AP) blockade. However, a recent study showed that $\mathrm{Kv} 4.1$ in the hippocampus has unique electrophysiological characteristics and expression patterns distinctive from those of Kv4.2 [27]. Kv4.2 was shown to mediate $\mathrm{I}_{\mathrm{A}}$ in CA1 pyramidal neurons, regulating AP repolarization phase [61-63], while Kv4.1 was weakly expressed and had no role in CA1 pyramidal neurons [27]. Interesingly, Kv4.1 expression was significant in DG, and Kv4.1-mediated currents detected only in low-frequency firing mature GCs displayed slow inactivation kinetics [27]. Inhibition of Kv4.1 currents by shRNA or antibody induced a significant increase in firing frequency [27], suggesting that Kv4.1 played a key role in lowering firing frequency in mature GCs. Furthermore, specific knockdown of Kv4.1 in the DG region selectively impaired conditional freezing between similar contexts, suggesting that low frequency firing of mature GCs is crucial for pattern separation [27]. The present study highlights Kv4.1 as a target ion channel that causes hyperexcitability of DG in AD, leading to impaired pattern separation. 
Aa

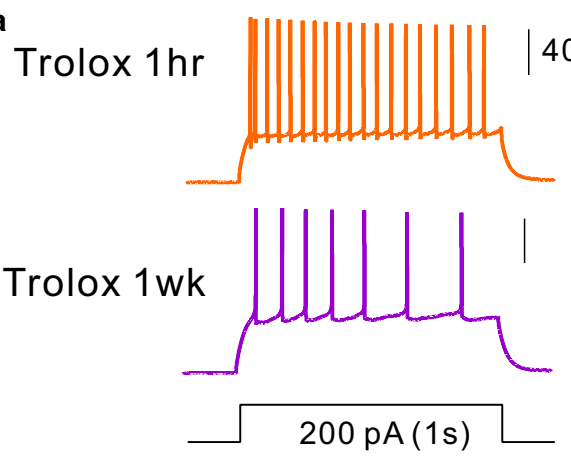

B

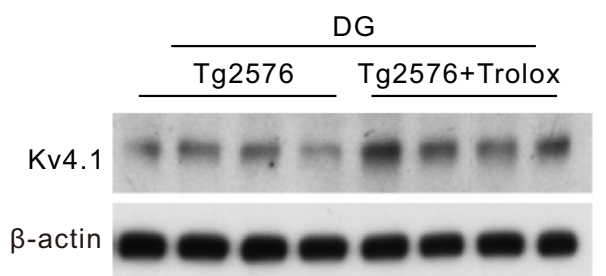

$\mathrm{Ca}$

+ Trolox i.p. injection

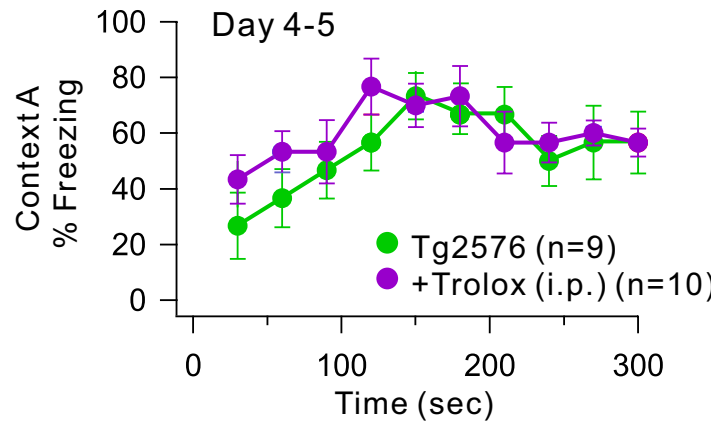

Da

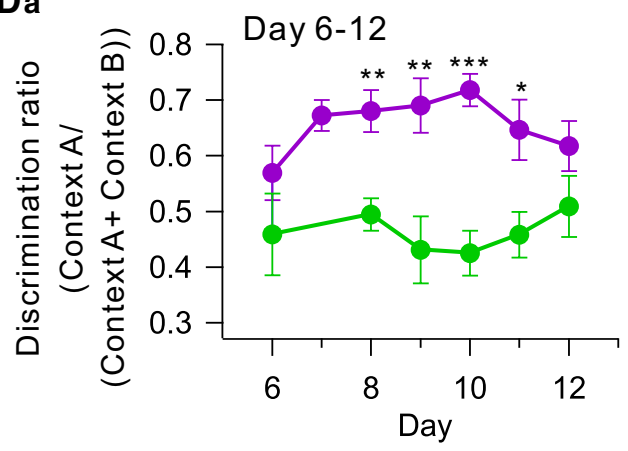

Ab $\quad--W T \quad O \mathrm{Tg}+\operatorname{Trolox}(1 \mathrm{hr})$

$\cdot-\mathrm{Tg} 2576 \bullet \mathrm{Tg}+\operatorname{Trolox}(1 \mathrm{wk})$
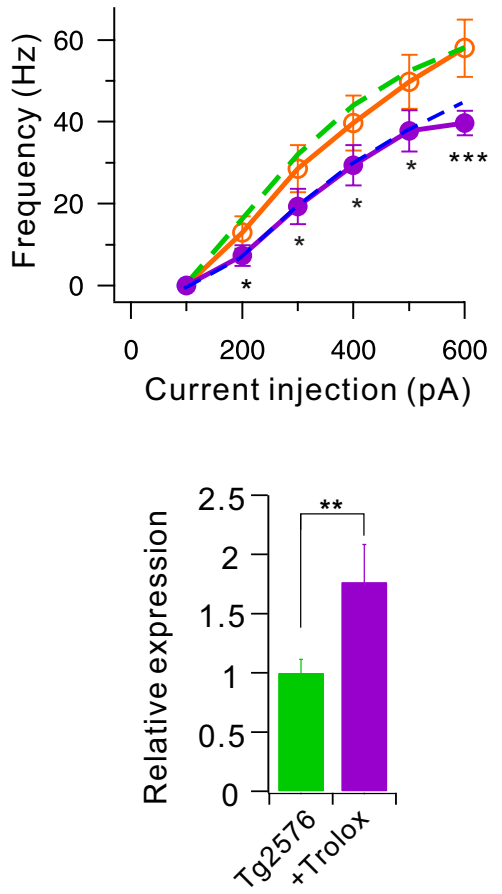

$\mathrm{Cb}$

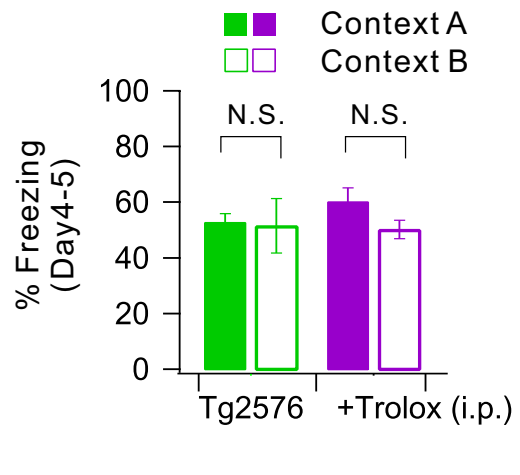

Db

Context $\mathrm{A}$

$\square \square$ Context B

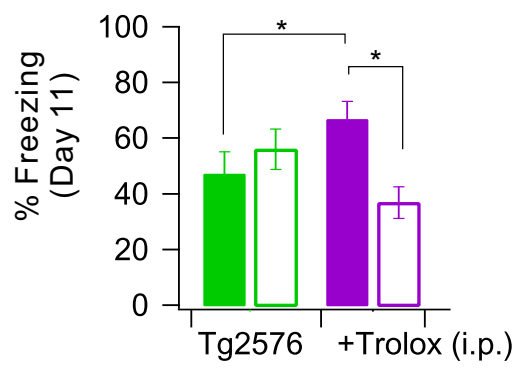


Our previous study suggested that dentate GCs may be the earliest target for AD-associated oxidative stress [22]. The present study implies that overproduction of ROS is responsible for the reduction of Kv4.1 expression in the young Tg2576 mice. The molecular mechanism how oxidative stress involved in AD pathology decreases Kv4.1 expression remains to be investigated. ROS-dependent regulation of channel expression is little understood in neurons, whereas a few studies in non-neuronal cells showed that ROS exerts diverse effects on expression and activity of $\mathrm{Na}^{+}, \mathrm{K}^{+}$and $\mathrm{Ca}^{2+}$ channels [64-66]. Mitochondria are not only the major source of ROS but also the primary target of ROS, which induces cellular dysfunction. Overproduction of ROS in Tg2576 mice is correlated with mitochondrial $A \beta$ accumulation, probably leading to mitochondrial depolarization and the reduction in respiratory enzyme activities and oxygen consumption $[22,67,68]$. The treatment of Trolox on GCs of $\operatorname{Tg} 2576$ mice restored the mitochondrial function in parallel with the reduction of ROS in GCs [22]. Intriguingly, a recent study suggested that the setpoint of neuronal excitability may be regulated by mitochondrial oxygen consumption capacity [69]. It remains to be elucidated whether mitochondria are involved in ROS-mediated downregulation of Kv4.1 in Tg2576 mice.

\section{Materials and methods}

\section{Behavior analysis}

All experiments procedures were conducted in accordance with the guide lines of University Committee on Animal Resource in Seoul National University (Approval No. SNU-090115-7). Male Tg2576 transgenic mice and their littermate wild-type control (WT) mice aged 10-weeks were trained to discriminate between two similar contexts, A and B, through repeated experience in each context. Context A (conditioning context) was a chamber $(18 \mathrm{~cm}$ wide $\times 18 \mathrm{~cm}$ long $\times 30 \mathrm{~cm}$ high; H1011 M-TC; Coulbourn Instruments 5583, PA 18052, USA) consisting of a metal grid floor, aluminum side walls, and a clear Plexiglass front door and back wall. Context A was indirectly illuminated with a $12 \mathrm{~W}$ light bulb. The features of Context B (safe context) were the same as Context A, except for a unique scent (1\% acetic acid), dimmer light ( $50 \%$ of $\mathrm{A}$ ), and a sloped floor by $15^{\circ}$ angle. Each context was cleaned with $70 \%$ ethanol before the animals were placed. On the first 3 days (contextual fear acquisition), mice were placed in Context $\mathrm{A}$ for $3 \mathrm{~min}$ for exploring the environment, and then received a single foot shock $(0.75 \mathrm{~mA}$, for $2 \mathrm{~s})$. Mice were returned to their home cage $1 \mathrm{~min}$ after the shock. On day 4-5, mice of each genotype were divided into two groups; one group visited Context A on Day 4 and Context B on Day 5 , while the other group visited the Context B on Day 4 and Context A on Day 5. On day 4-5 (generalization), neither group received a shock in Context A and B, and freezing level was measured for 5 min only in Context A. We defined freezing behavior as behavioral immobility except for respiration movement. We observed video image for 2 -s bouts every $10 \mathrm{~s}$ (18 or 30 observation bouts for $3 \mathrm{~min}$ or $5 \mathrm{~min}$ recording time) and counted the number of 2-s bouts during which the mouse displayed freezing behavior (referred to as the freezing score). The percentage of freezing was calculated by dividing the freezing score with the total number of observation bouts (18 or 30$)$. Mice were subsequently trained to discriminate these two contexts by visiting the two contexts daily for 8 days (from day 6 to 13, discrimination task). Mice always received a foot shock ( $2 \mathrm{~s}) 3 \mathrm{~min}$ after being placed in Context A but not B. Discrimination ratios were calculated according to $F_{A} /\left(F_{A}+F_{B}\right)$, where $F_{A}$ and $F_{B}$ are freezing scores in Contexts $\mathrm{A}$ and $\mathrm{B}$, respectively. To test context specificity, mice were exposed to Context A and $\mathrm{C}$ for 5 min each on Day 1. On Day 2, mice were placed in Context A for 3 min followed by a foot shock (2 s), and returned to their home cage 1 min after the shock. Freezing behavior was observed on the next day (Day 3) in either Context A or C for $3 \mathrm{~min}$. All experiments and analyses were performed blind to the mice genotype.

\section{Preparation of brain slices}

Brain slices were prepared from male Tg2576 transgenic mice and their littermate wild-type control (WT) mice aged from 1 to 2 months old. Average ages of WT and $\operatorname{Tg} 2576$ used in the present study were 5.7 week $(n=75)$ and 5.8 week $(n=53)$, respectively. Experiments for dentate GCs were mostly conducted using mice at postnatal week (PW) 4 to PW 7, while experiments for CA1-PCs were conducted using mice at PW 3 to PW 4. For invivo antioxidant pretreatment experiments, age-matched male $\operatorname{Tg} 2576$ mice were assigned to receive 6-Hydroxy2,5,7,8-tetramethylchromane-2-carboxylic acid (Trolox, Sigma-Aldrich, St. Louis, MO) by intraperitoneal injection for 1 week. Trolox dosage was adopted from Betters et al. (2004), in which a $20 \mathrm{mg} / \mathrm{kg}$ priming dose was used to block oxidative stress [70]. Mice were killed by decapitation after being anesthetized with isoflurane, and the whole brain was immediately removed from the skull and chilled in artificial cerebrospinal fluid (aCSF) containing (in mM): $125 \mathrm{NaCl}, 25 \mathrm{NaHCO}_{3}, 2.5 \mathrm{KCl}$, $1.25 \mathrm{NaH}_{2} \mathrm{PO}_{4}, 2 \mathrm{CaCl}_{2}, 1 \mathrm{MgCl}_{2}, 20$ glucose, 1.2 pyruvate and 0.4 Na-ascorbate, $\mathrm{pH} 7.4$ when saturated with carbogen $\left(95 \% \mathrm{O}_{2}\right.$ and $\left.5 \% \mathrm{CO}_{2}\right)$ at $4{ }^{\circ} \mathrm{C}$. Transverse hippocampal slices $(350 \mu \mathrm{m}$ thick) were prepared using a vibratome (VT1200S, Leica, Germany). Slices were incubated at $35{ }^{\circ} \mathrm{C}$ for $30 \mathrm{~min}$ and thereafter maintained at 
$32{ }^{\circ} \mathrm{C}$ until in situ slice patch recordings and fluorescence microscopy.

\section{Electrophysiological analysis for excitability and $\mathrm{K}^{+}$ currents}

Hippocampal GCs of DG were visualized using an upright microscope equipped with differential interference contrast (DIC) optics (BX51WI, Olympus, Japan). Electrophysiological recordings were made by the whole cell clamp technique with EPC-8 amplifier (HEKA, Lambrecht, Germany). Experiments were performed at $32 \pm 1{ }^{\circ} \mathrm{C}$. The perfusion rate of bathing solution and the volume of the recording chamber for slices were $2.2 \mathrm{ml} / \mathrm{min}$ and $1.2 \mathrm{ml}$, respectively. Patch pipettes with a tip resistance of 3-4 M $\Omega$ were used. The series resistance $\left(R_{s}\right)$ after establishing whole-cell configuration was between 10 and $15 \mathrm{M} \Omega$. $\mathrm{R}_{\mathrm{s}}$ was monitored by applying a short $(40 \mathrm{~ms})$ hyperpolarization $(5 \mathrm{mV})$ pulse during the recording. The pipette solution contained (in $\mathrm{mM}$ ): $143 \mathrm{~K}$-gluconate, $7 \mathrm{KCl}, 15 \mathrm{HEPES}, 4 \mathrm{MgATP}, 0.3 \mathrm{NaGTP}$, $4 \mathrm{Na}$-ascorbate, and 0.1 EGTA with the $\mathrm{pH}$ adjusted to 7.3 with $\mathrm{KOH}$. For the antibody-blocking experiments, patch pipettes were dipped into an internal solution and then back-filled with the internal solution containing the antibody of Kv4.1 at a concentration of $0.3 \mu \mathrm{g} / \mathrm{ml}$. In all bath solutions (aCSF), $20 \mu \mathrm{M}$ bicuculine and $10 \mu \mathrm{M}$ CNQX were included to block the synaptic inputs. In voltage clamp experiments to record $\mathrm{K}^{+}$currents, we added TTX $(0.5 \mu \mathrm{M}), \mathrm{CdCl}_{2}(300 \mu \mathrm{M})$ and $\mathrm{NiCl}_{2}(500 \mu \mathrm{M})$ to block $\mathrm{Na}^{+}$and $\mathrm{Ca}^{2+}$ channels, and membrane potentials were depolarized to a maximum of $30 \mathrm{mV}$ for $1 \mathrm{~s}$ by $10 \mathrm{mV}$ increments from the holding potential of $-70 \mathrm{mV}$. In current clamp experiments to analyze neuronal excitability, the following parameters were measured: (1) the resting membrane potential, (2) the input resistance $\left(R_{i n}\right.$, membrane potential changes $(\mathrm{V})$ for given hyperpolarizing current (- $35 \mathrm{pA}, 600 \mathrm{~ms}$ ) input), (3) AP threshold (current threshold for single action potential generation, $100 \mathrm{~ms}$ duration), (4) F-I curve (firing frequency (F) against the amplitude of injected currents (I), for DG; $100 \mathrm{pA}$ to $600 \mathrm{pA}, 100 \mathrm{pA}$ increment, $1 \mathrm{~s}$ duration, for CA1 pyramidal cells (CA1 PCs); $50 \mathrm{pA}$ to $250 \mathrm{pA}, 50$ $\mathrm{pA}$ increment, $1 \mathrm{~s}$ duration). Membrane potentials are given without correction for liquid junction potentials. All chemicals were obtained from Sigma (St. Louis, MO, USA), except CNQX, bicuculline, and TTX purchase from abcam Biochemicals (Cambridge, UK).

\section{RNA extraction and Quantitative real-time PCR (qRT-PCR)}

Total RNA was isolated from mouse hippocampal DG region using TRIzol reagent (Invitrogen, Carlsbad, CA). We used 1- to 2-month-old male WT and Tg2576 mouse.
cDNA was produced from $1 \mu \mathrm{g}$ of total isolated RNA using the Invitrogen superscript III First-strand synthesis system for RT-PCR (Cat.18080-051) from Invitrogen. The expression levels of Kv4.1, Kv4.2, Kv4.3, and GAPDH were determined using sequence specific primers and Power SYBR ${ }^{\circledR}$ Green PCR Master Mix (Applied Biosystems, Part No. 4367659) for qRT-PCR, experiments were conducted on a 7900HT Fast Real-Time PCR System (Applied Biosystems). Primers used in qRT-PCR reactions as follows ( $5^{\prime}$ - to $\left.-3^{\prime}\right)$ : GAPDH, GCAACAGGG TGGTGGACCT (forward) and GGATAGGGCCTCTCT TGCTCA (reverse), Kv4.1, GCCGCAGTACCTCAG TATCATC (forward) and GACAGAGGCAGTAGAGTT GGCA (reverse), Kv4.2, ATCGCCCATCAAGTCACA GTC (forward) and CCGACACATTGGCATTAGGAA (reverse), Kv4.3, AGATTACCACGGCCATCATC (forward) and GGAAGGAATGTTCGTGTTGG (reverse). Data were analyzed using the threshold cycle relative quantification method, with GAPDH as the endogenous control. Real-time PCR was performed in duplicate using the same amplification protocol described above.

\section{Western blot analysis}

DG region was isolated from slices under the dissecting microscope. Isolated tissues were homogenized with a glass homogenizer in TNE buffer $(50 \mathrm{mM}$ Tris- $\mathrm{HCl}$, $\mathrm{pH} 8.0,150 \mathrm{mM} \mathrm{NaCl}$, and $2 \mathrm{mM}$ EDTA) supplemented with protease inhibitor cocktails (Roche), and sonicated for $10 \mathrm{~s}$. After adding SDS (0.5\%) and Triton X-100 (1\%), lysates were incubated for $30 \mathrm{~min}$ at $4{ }^{\circ} \mathrm{C}$. Insoluble materials were removed by centrifugation at $20,000 \times g$ for $15 \mathrm{~min}$ at $4{ }^{\circ} \mathrm{C}$. The amount of protein in the supernatants were determined by the BCA assay, and supernatants were mixed with $6 \times$ Laemmli sample buffer. Samples containing $20 \mu \mathrm{g}$ protein were loaded into each lane, separated by SDS-PAGE, and transferred to a PVDF membrane. Membranes were blocked in $5 \%$ skim milk in TBS for $1 \mathrm{~h}$, and then probed with the relevant antibodies as indicated. Membranes were then incubated with peroxidase-conjugated secondary antibodies, and blots were detected with chemiluminescent reagents (Thermo Scientific). Antibodies to Kv4.1 and $\beta$-actin for Western blot analysis were purchased from Alomone lab (APC$119)$ and Cell signaling (\#4970), respectively.

\section{Statistical analysis}

Data were analyzed with Igor Pro (Version 6; Wavemetrics, Lake Oswego, CA) and Origin (Version 8; Microcal, Northampton, MA). All results are presented as mean \pm S.E.M. with the number of cells or mice (n) used in each experiment. Statistical significance was evaluated using Student's t-test or Mann-Whitney test, and the level of significance was indicated by the 
number of marks (*, $\mathrm{P}<0.05$; **, $\mathrm{P}<0.01$; ***, $\mathrm{P}<0.001$ ). $\mathrm{P}>0.05$ was regarded as not significantly different (N.S.). Comparison between multifactorial statistical data was made using the two-way analysis of variance (ANOVA). Differences in time-dependent changes of behavioral parameters between the two genotypes were evaluated using two-way repeated measures ANOVA.

\begin{abstract}
Abbreviations
aCSF: Artificial corticospinal fluid; AD: Alzheimer's disease; 4-AP: 4-Aminopyridine; AP: Action potential; AB: Amyloid $\beta ; C A 1$ : Cornu Ammonis 1 area of hippocampus; CA3: Cornu Ammonis 3 area of hippocampus; CNQX: 6-Cyano7-nitroquinoxaline-2,3-dione; DG: Dentate gyrus; fMRI: Functional magnetic resonance imaging; $\mathrm{GABA}_{A}$ receptors: Gamma-aminobutyric acid receptors, subtype A; GCs: Granule cells; I: A-type potassium currents; I peak: Peak current: $\mathrm{I}_{\mathrm{ss}}$ : Steady state current; Kv4: Voltage-dependent potassium channel subfamily 4; L2/3: Cortical layer 2/3; LTP: Long-term potentiation; MF: Mossy fiber; qRTPCR: Quantitative real-time polymerase chain reaction; $R_{\text {in }}$ : Input resistance; RMP: Resting membrane potential; ROS: Reactive oxygen species; shRNA: Small hairpin ribonucleic acid; TTX:Tetrodotoxin;WT: Wild-type.
\end{abstract}

\section{Supplementary Information}

The online version contains supplementary material available at https://doi. org/10.1186/s13041-021-00774-x.

Additional file 1: Figure S1. Comparison of the freezing levels in context $A$ and $B$ during contextual fear discrimination test.

Acknowledgements

Not applicable.

\section{Authors' contributions}

$\mathrm{KK}, \mathrm{YK}_{1}, \mathrm{HJ}$ performed experiments and analyzed data. $\mathrm{KK}, \mathrm{JK}, \mathrm{SL}_{2}, \mathrm{WH}$ designed experiments. KK, WH wrote the first draft of the manuscript. $\mathrm{SL}_{1}, \mathrm{YK}_{2}$, WH edited the manuscript. All authors approved the final manuscript. $Y_{1}$ : Yoonsub Kim, YK ${ }_{2}$ :Yujin Kim, SL 1 : Sang Hun Lee, $\mathrm{SL}_{2}$ : Suk-Ho Lee.

\section{Funding}

This research was supported by the Korean Ministry of Science and ICT (NRF2017R1A2B2010186 and NRF-2020R1A2B5B02002070 to WH).

\section{Availability of data and materials}

The datasets generated and/or analyzed during the current study are available from the corresponding author on reasonable request.

\section{Declarations}

\section{Ethics approval and consent to participate}

All experiments procedures were conducted in accordance with the guide lines of University Committee on Animal Resource in Seoul National University (Approval No. SNU-090115-7).

\section{Consent for publication}

Not applicable.

\section{Competing interest}

The authors declare that they have no conflict of interest.

\section{Author details}

${ }^{1}$ Department of Physiology, Seoul National University College of Medicine, 103 Daehak-ro, Jongno-gu, Seoul 03080, Korea. ${ }^{2}$ Neuroscience Research Institute, Seoul National University College of Medicine, Seoul, Korea. ${ }^{3}$ Department of Brain and Cognitive Science, Seoul National University College of Natural Science, Seoul, Korea. ${ }^{4}$ Department of Molecular Cell Biology,
Sungkyunkwan University School of Medicine, Suwon, Korea. ${ }^{5}$ Present Address: Department of Neurology, Brigham and Women's Hospital, Harvard Medical School, Boston, MA 02115, USA.

Received: 4 February 2021 Accepted: 23 March 2021

Published online: 30 March 2021

\section{References}

1. Bäckman L, Jones S, Berger A-K, Laukka EJ, Small BJ. Cognitive impairment in preclinical Alzheimer's disease: a meta-analysis. Neuropsychology. 2005;19(4):520.

2. Chen P, Ratcliff G, Belle SH, Cauley JA, DeKosky ST, Ganguli M. Patterns of cognitive decline in presymptomatic Alzheimer disease: a prospective community study. Arch Gen Psychiatry. 2001;58(9):853-8.

3. Elias MF, Beiser A, Wolf PA, Au R, White RF, D'Agostino RB. The preclinical phase of Alzheimer disease: a 22-year prospective study of the Framingham Cohort. Arch Neurol. 2000;57(6):808-13.

4. Small BJ, Herlitz A, Fratiglioni L, Almkvist O, Bäckman L. Cognitive predictors of incident Alzheimer's disease: a prospective longitudinal study. Neuropsychology. 1997;11(3):413.

5. Forner S, Baglietto-Vargas D, Martini AC, Trujillo-Estrada L, LaFerla FM. Synaptic impairment in Alzheimer's disease: a dysregulated symphony. Trends Neurosci. 2017;40(6):347-57.

6. Jacobsen JS, Wu C-C, Redwine JM, Comery TA, Arias R, Bowlby M, et al. Early-onset behavioral and synaptic deficits in a mouse model of Alzheimer's disease. Proc Natl Acad Sci. 2006;103(13):5161-6.

7. Li K, Wei Q, Liu F-F, Hu F, Xie A-j, Zhu L-Q, et al. Synaptic dysfunction in Alzheimer's disease: a $\beta$, tau, and epigenetic alterations. Mol Neurobiol. 2018:55(4):3021-32

8. Busche MA, Eichhoff G, Adelsberger H, Abramowski D, Wiederhold K-H, Haass $C$, et al. Clusters of hyperactive neurons near amyloid plaques in a mouse model of Alzheimer's disease. Science. 2008;321(5896):1686-9.

9. Zott B, Busche MA, Sperling RA, Konnerth A. What happens with the circuit in Alzheimer's disease in mice and humans? Annu Rev Neurosci. 2018;41:277-97.

10. Palop JJ, Mucke L. Epilepsy and cognitive impairments in Alzheimer disease. Arch Neurol. 2009:66(4):435-40.

11. Ally BA, Hussey EP, Ko PC, Molitor RJ. Pattern separation and pattern completion in Alzheimer's disease: evidence of rapid forgetting in amnestic mild cognitive impairment. Hippocampus. 2013;23(12):1246-58.

12. Braak H, Braak E. Neuropathological stageing of Alzheimer-related changes. Acta Neuropathol. 1991;82(4):239-59.

13. Braak H, Thal DR, Ghebremedhin E, Del Tredici K. Stages of the pathologic process in Alzheimer disease: age categories from 1 to 100 years. J Neuropathol Exp Neurol. 2011;70(11):960-9.

14. Gómez-Isla T, Price JL, McKeel DW Jr, Morris JC, Growdon JH, Hyman BT. Profound loss of layer II entorhinal cortex neurons occurs in very mild Alzheimer's disease. J Neurosci. 1996;16(14):4491-500.

15. Amaral DG, Witter MP. The three-dimensional organization of the hippocampal formation: a review of anatomical data. Neuroscience. 1989:31(3):571-91.

16. Klausberger T, Somogyi P. Neuronal diversity and temporal dynamics: the unity of hippocampal circuit operations. Science. 2008;321(5885):53-7.

17. Kesner RP. A process analysis of the CA3 subregion of the hippocampus. Front Cell Neurosci. 2013:7:78.

18. Yassa MA, Stark CE. Pattern separation in the hippocampus. Trends Neurosci. 2011;34(10):515-25.

19. Yassa MA, Lacy JW, Stark SM, Albert MS, Gallagher M, Stark CE. Pattern separation deficits associated with increased hippocampal CA3 and dentate gyrus activity in nondemented older adults. Hippocampus. 2011;21(9):968-79.

20. Yassa MA, Stark SM, Bakker A, Albert MS, Gallagher M, Stark CE. Highresolution structural and functional MRI of hippocampal CA3 and dentate gyrus in patients with amnestic mild cognitive impairment. Neuroimage. 2010;51(3):1242-52

21. Palmer A, Good M. Hippocampal synaptic activity, pattern separation and episodic-like memory: implications for mouse models of Alzheimer's disease pathology. Portland Press Ltd.; 2011. 
22. Lee SH, Kim K-R, Ryu S-Y, Son S, Hong HS, Mook-Jung I, et al. Impaired short-term plasticity in mossy fiber synapses caused by mitochondrial dysfunction of dentate granule cells is the earliest synaptic deficit in a mouse model of Alzheimer's disease. J Neurosci. 2012;32(17):5953-63.

23. Viana da Silva S, Zhang P, Haberl MG, Labrousse V, Grosjean N, Blanchet C, et al. Hippocampal mossy fibers synapses in CA3 pyramidal cells are altered at an early stage in a mouse model of Alzheimer's disease. J Neurosci. 2019;39(21):4193-205.

24. Rolls E. The mechanisms for pattern completion and pattern separation in the hippocampus. Front Syst Neurosci. 2013;7:74.

25. Treves A, Rolls ET. Computational analysis of the role of the hippocampus in memory. Hippocampus. 1994;4(3):374-91.

26. Jinde S, Zsiros V, Jiang Z, Nakao K, Pickel J, Kohno K, et al. Hilar mossy cell degeneration causes transient dentate granule cell hyperexcitability and impaired pattern separation. Neuron. 2012;76(6):1189-200.

27. Kim K-R, Lee SY, Yoon SH, Kim Y, Jeong H-J, Lee S, et al. Kv4.1, a key ion channel for low frequency firing of dentate granule cells, is crucial for pattern separation. J Neurosci. 2020;40(11):2200-14.

28. McHugh TJ, Jones MW, Quinn JJ, Balthasar N, Coppari R, Elmquist JK, et al. Dentate gyrus NMDA receptors mediate rapid pattern separation in the hippocampal network. Science. 2007;317(5834):94-9.

29. Chapman PF, White GL, Jones MW, Cooper-Blacketer D, Marshall VJ, Irizarry $M$, et al. Impaired synaptic plasticity and learning in aged amyloid precursor protein transgenic mice. Nat Neurosci. 1999;2(3):271-6.

30. Schmidt-Hieber C, Jonas P, Bischofberger J. Enhanced synaptic plasticity in newly generated granule cells of the adult hippocampus. Nature. 2004:429(6988):184-7.

31. Lee SH, Kim KR, Ryu SY, Son S, Hong HS, Mook-Jung I, Ho WK. Impaired short-term plasticity in mossy fiber synapses caused by mitochondrial dysfunction of dentate granule cells is the earliest synaptic deficit in a mouse model of Alzheimer's disease. J Neurosci: Off J Soc Neurosci. 2012;32(17):5953-63.

32. Kim K-R, Jeong H-J, Kim Y, Lee SY, Kim Y, Kim H-J, et al. Calbindin regulates Kv4.1 trafficking and excitability of dentate granule cells via CaMKIl-dependent phosphorylation. bioRxiv. 2021.

33. Eslamizade M, Saffarzadeh F, Mousavi S, Meftahi G, Hosseinmardi N, Mehdizadeh $\mathrm{M}$, et al. Alterations in CA1 pyramidal neuronal intrinsic excitability mediated by Ih channel currents in a rat model of amyloid beta pathology. Neuroscience. 2015;305:279-92.

34. Kaczorowski C, Sametsky E, Shah S, Vassar R, Disterhoft J. Mechanisms underlying basal and learning-related intrinsic excitability in a mouse model of Alzheimer's disease. Neurobiol Aging. 2011;32(8):1452-65.

35. Brown JT, Chin J, Leiser SC, Pangalos MN, Randall AD. Altered intrinsic neuronal excitability and reduced $\mathrm{Na}+$ currents in a mouse model of Alzheimer's disease. Neurobiol Aging. 2011;32(11):2109.

36. Kerrigan T, Brown J, Randall A. Characterization of altered intrinsic excitability in hippocampal CA1 pyramidal cells of the A $\beta$-overproducing PDAPP mouse. Neuropharmacology. 2014;79:515-24.

37. Scala F, Fusco S, Ripoli C, Piacentini R, Puma DDL, Spinelli M, et al. Intraneuronal $A \beta$ accumulation induces hippocampal neuron hyperexcitability through A-type $\mathrm{K}+$ current inhibition mediated by activation of caspases and GSK-3. Neurobiol Aging. 2015;36(2):886-900.

38. Oh MM, Simkin D, Disterhoft JF. Intrinsic hippocampal excitability changes of opposite signs and different origins in CA1 and CA3 pyramidal neurons underlie aging-related cognitive deficits. Front Syst Neurosci. 2016;10:52.

39. Simkin D, Hattori S, Ybarra N, Musial TF, Buss EW, Richter H, et al. Aging-related hyperexcitability in CA3 pyramidal neurons is mediated by enhanced A-type $\mathrm{K}+$ channel function and expression. J Neurosci. 2015;35(38):13206-18.

40. Haberman RP, Koh MT, Gallagher M. Heightened cortical excitability in aged rodents with memory impairment. Neurobiol Aging. 2017;54:144-51.

41. Bakker A, Krauss GL, Albert MS, Speck CL, Jones LR, Stark CE, et al. Reduction of hippocampal hyperactivity improves cognition in amnestic mild cognitive impairment. Neuron. 2012;74(3):467-74.

42. Cumbo E, Ligori LD. Levetiracetam, lamotrigine, and phenobarbital in patients with epileptic seizures and Alzheimer's disease. Epilepsy Behav. 2010;17(4):461-6.

43. Sola I, Aso E, Frattini D, López-González I, Espargaro A, Sabaté R, et al. Novel levetiracetam derivatives that are effective against the
Alzheimer-like phenotype in mice: synthesis, in vitro, ex vivo, and in vivo efficacy studies. J Med Chem. 2015;58(15):6018-32.

44. Hall AM, Throesch BT, Buckingham SC, Markwardt SJ, Peng Y, Wang Q, et al. Tau-dependent Kv4.2 depletion and dendritic hyperexcitability in a mouse model of Alzheimer's disease. J Neurosci. 2015;35(15):6221-30.

45. Minkeviciene R, Rheims S, Dobszay MB, Zilberter M, Hartikainen J, Fülöp L, et al. Amyloid $\beta$-induced neuronal hyperexcitability triggers progressive epilepsy. J Neurosci. 2009;29(11):3453-62.

46. Palop JJ, Chin J, Roberson ED, Wang J, Thwin MT, Bien-Ly N, et al. Aberrant excitatory neuronal activity and compensatory remodeling of inhibitory hippocampal circuits in mouse models of Alzheimer's disease. Neuron. 2007:55(5):697-711.

47. Palop JJ, Mucke L. Network abnormalities and interneuron dysfunction in Alzheimer disease. Nat Rev Neurosci. 2016;17(12):777-92.

48. Lam AD, Deck G, Goldman A, Eskandar EN, Noebels J, Cole AJ. Silent hippocampal seizures and spikes identified by foramen ovale electrodes in Alzheimer's disease. Nat Med. 2017;23(6):678-80.

49. Vossel KA, Beagle AJ, Rabinovici GD, Shu H, Lee SE, Naasan G, et al. Seizures and epileptiform activity in the early stages of Alzheimer disease. JAMA Neurol. 2013;70(9):1158-66.

50. Zott B, Simon MM, Hong W, Unger F, Chen-Engerer H-J, Frosch MP, et al. A vicious cycle of $\beta$ amyloid-dependent neuronal hyperactivation. Science. 2019;365(6453):559-65.

51. Cirrito JR, Yamada KA, Finn MB, Sloviter RS, Bales KR, May PC, et al. Synaptic activity regulates interstitial fluid amyloid-beta levels in vivo. Neuron. 2005;48(6):913-22.

52. Noebels JL. Modeling human epilepsies in mice. Epilepsia. 2001;42:11-5.

53. Verret L, Mann EO, Hang GB, Barth AM, Cobos I, Ho K, et al. Inhibitory interneuron deficit links altered network activity and cognitive dysfunction in Alzheimer model. Cell. 2012;149(3):708-21.

54. Sloviter RS. "Epileptic" brain damage in rats induced by sustained electrical stimulation of the perforant path. I. Acute electrophysiological and light microscopic studies. Brain Res Bull. 1983;10(5):675-97.

55. Sloviter RS, Bumanglag AV, Schwarcz R, Frotscher M. Abnormal dentate gyrus network circuitry in temporal lobe epilepsy. Jasper's Basic Mechanisms of the Epilepsies [Internet] 4th edition: National Center for Biotechnology Information (US); 2012.

56. Perusini JN, Cajigas SA, Cohensedgh O, Lim SC, Pavlova IP, Donaldson ZR, et al. Optogenetic stimulation of dentate gyrus engrams restores memory in Alzheimer's disease mice. Hippocampus. 2017;27(10):1110-22.

57. Roy DS, Arons A, Mitchell TI, Pignatelli M, Ryan TJ, Tonegawa S. Memory retrieval by activating engram cells in mouse models of early Alzheimer's disease. Nature. 2016;531(7595):508-12.

58. Baldwin TJ, Tsaur M-L, Lopez GA, Jan YN, Jan LY. Characterization of a mammalian cDNA for an inactivating voltage-sensitive $\mathrm{K}+$ channel. Neuron. 1991;7(3):471-83.

59. Pak MD, Baker K, Covarrubias M, Butler A, Ratcliffe A, Salkoff L. mShal, a subfamily of A-type K+ channel cloned from mammalian brain. Proc Natl Acad Sci. 1991;88(10):4386-90.

60. Serodio P, Vega-Saenz de Miera E, Rudy B. Cloning of a novel component of A-type $\mathrm{K}+$ channels operating at subthreshold potentials with unique expression in heart and brain. J Neurophysiol. 1996;75(5):2174-9.

61. Chen X, Yuan LL, Zhao C, Birnbaum SG, Frick A, Jung WE, et al. Deletion of Kv4.2 gene eliminates dendritic A-type K+ current and enhances induction of long-term potentiation in hippocampal CA1 pyramidal neurons. J Neurosci. 2006;26(47):12143-51.

62. Kim J, Wei DS, Hoffman DA. Kv4 potassium channel subunits control action potential repolarization and frequency-dependent broadening in rat hippocampal CA1 pyramidal neurones. J Physiol. 2005;569(Pt 1):41-57.

63. Kim J, Jung SC, Clemens AM, Petralia RS, Hoffman DA. Regulation of dendritic excitability by activity-dependent trafficking of the A-type $\mathrm{K}+$ channel subunit Kv4.2 in hippocampal neurons. Neuron. 2007;54(6):933-47.

64. Jerng HH, Pfaffinger PJ. S-glutathionylation of an auxiliary subunit confers redox sensitivity to Kv4 channel inactivation. PLoS ONE. 2014;9(3):e93315.

65. Liu M, Gu L, Sulkin MS, Liu H, Jeong E-M, Greener I, et al. Mitochondrial dysfunction causing cardiac sodium channel downregulation in cardiomyopathy. J Mol Cell Cardiol. 2013;54:25-34.

66. Peers C, Scragg JL, Boyle JP, Fearon IM, Taylor SC, Green KN, et al. A central role for ROS in the functional remodelling of L-type Ca2+ 
channels by hypoxia. Philosophical Trans Royal Soc B: Biol Sci. 2005;360(1464):2247-54.

67. Caspersen C, Wang N, Yao J, Sosunov A, Chen X, Lustbader JW, et al. Mitochondrial $A \beta$ : a potential focal point for neuronal metabolic dysfunction in Alzheimer's disease. FASEB J. 2005;19(14):2040-1.

68. Manczak M, Anekonda TS, Henson E, Park BS, Quinn J, Reddy PH. Mitochondria are a direct site of $A \beta$ accumulation in Alzheimer's disease neurons: implications for free radical generation and oxidative damage in disease progression. Hum Mol Genet. 2006;15(9):1437-49.

69. Styr B, Gonen N, Zarhin D, Ruggiero A, Atsmon R, Gazit N, et al. Mitochondrial regulation of the hippocampal firing rate set point and seizure susceptibility. Neuron. 2019;102(5):1009-24.
70. Betters JL, Criswell DS, Shanely RA, Van Gammeren D, Falk D, DeRuisseau KC, et al. Trolox attenuates mechanical ventilation-induced diaphragmatic dysfunction and proteolysis. Am J Respir Crit Care Med. 2004;170(11):1179-84.

\section{Publisher's Note}

Springer Nature remains neutral with regard to jurisdictional claims in published maps and institutional affiliations.
Ready to submit your research? Choose BMC and benefit from:

- fast, convenient online submission

- thorough peer review by experienced researchers in your field

- rapid publication on acceptance

- support for research data, including large and complex data types

- gold Open Access which fosters wider collaboration and increased citations

- maximum visibility for your research: over $100 \mathrm{M}$ website views per year

At BMC, research is always in progress.

Learn more biomedcentral.com/submissions 